See discussions, stats, and author profiles for this publication at: https://www.researchgate.net/publication/256563249

\title{
Inclusive curricula in Spanish higher education? Students with disabilities speak out
}

Article in Disability \& Society · April 2013

DOI: 10.1080/09687599.2013.769862

\section{CITATIONS}

36

3 authors, including:

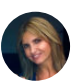

Universidad de Sevilla

122 PUBLICATIONS 996 CITATIONS

SEE PROFILE
READS

200

M Dolores Cortés Vega

Universidad de Sevilla

28 PUBLICATIONS 191 CITATIONS

SEE PROFILE

Some of the authors of this publication are also working on these related projects:

Project Inclusive Pedagogy in the University: faculty members's narratives View project

Project Sistema de Indicadores de Atención a la Diversidad en el Ámbito Universitario View project 
This article was downloaded by: [University of Regina]

On: 06 August 2013, At: 08:35

Publisher: Routledge

Informa Ltd Registered in England and Wales Registered Number: 1072954 Registered

office: Mortimer House, 37-41 Mortimer Street, London W1T 3J H, UK

\title{
Disability \& Society
}

Publication details, including instructions for authors and subscription information: http:// www.tandfonline.com/loi/ cdso20

\section{Inclusive curricula in Spanish higher education? Students with disabilities speak out}

\author{
Anabel Moriña ${ }^{a}$, María Dolores Cortés ${ }^{b} \&$ Noelia Melero ${ }^{c}$ \\ a Facultad de Ciencias de la Educación, Didáctica y Organización \\ Educativa, C/ Pirotecnia, s/n, Seville, Spain \\ ${ }^{b}$ Departamento de Fisioterapia, Facultad de Enfermería, \\ Fisioterapia y Podología, Avda. Sanchez Pinjuan, S/n, Seville, \\ Spain \\ ${ }^{\mathrm{C}}$ Facultad de Ciencias de la Eduación, Teoría e Historia de la \\ Educación, C/ Pirotecnia, s/n, Seville, Spain \\ Published online: 25 Mar 2013.
}

To cite this article: Disability \& Society (2013): Inclusive curricula in Spanish higher education? Students with disabilities speak out, Disability \& Society, DOI: 10.1080/ 09687599. 2013.769862

To link to this article: http:// dx.doi.org/ 10.1080/ 09687599.2013.769862

\section{PLEASE SCROLL DOWN FOR ARTICLE}

Taylor \& Francis makes every effort to ensure the accuracy of all the information (the "Content") contained in the publications on our platform. However, Taylor \& Francis, our agents, and our licensors make no representations or warranties whatsoever as to the accuracy, completeness, or suitability for any purpose of the Content. Any opinions and views expressed in this publication are the opinions and views of the authors, and are not the views of or endorsed by Taylor \& Francis. The accuracy of the Content should not be relied upon and should be independently verified with primary sources of information. Taylor and Francis shall not be liable for any losses, actions, claims, proceedings, demands, costs, expenses, damages, and other liabilities whatsoever or howsoever caused arising directly or indirectly in connection with, in relation to or arising out of the use of the Content.

This article may be used for research, teaching, and private study purposes. Any substantial or systematic reproduction, redistribution, reselling, loan, sub-licensing, systematic supply, or distribution in any form to anyone is expressly forbidden. Terms \& 
Conditions of access and use can be found at http://www.tandfonline.com/page/termsand-conditions 


\title{
Inclusive curricula in Spanish higher education? Students with disabilities speak out
}

\author{
Anabel Moriña $^{\mathrm{a} *}$, María Dolores Cortés ${ }^{\mathrm{b}}$ and Noelia Melero ${ }^{\mathrm{c}}$ \\ ${ }^{a}$ Facultad de Ciencias de la Educación, Didáctica y Organización Educativa, C/ Pirotecnia, \\ $s / n$, Seville, Spain; ${ }^{b}$ Facultad de Enfermería, Fisioterapia y Podología, Departamento de \\ Fisioterapia, Avda. Sanchez Pinjuan, S/n, Seville, Spain; ${ }^{c}$ Facultad de Ciencias de la \\ Eduación, Teoría e Historia de la Educación, C/ Pirotecnia, s/n, Seville, Spain
}

(Received 9 March 2012; final version received 18 January 2013)

\begin{abstract}
This paper studies barriers and support affecting access, experience and performance as identified by students with disabilities at the University of Seville. Biographical-narrative research methodology is employed and the study is limited to an analysis of the design and development of subjects across the curriculum. Findings, which give voice to the students themselves, are organized in four topic areas: subject structure, methodology, tutorials, and assessment. The paper concludes with a review and discussion of key findings as well as suggestions for improvement and policy-making.
\end{abstract}

Keywords: higher education; students with disabilities; barriers; support; biographical-narrative method

\section{Points of interest}

- Higher education is not prepared for the inclusion of disabled students, so changes are required in the teaching and learning practices.

- Although both barriers and support are present in the curricula, the first are more frequent. Therefore, it is necessary to adopt measures to eliminate them.

- A legal vacuum in higher education: regulation exists for curricular adaptations for disabled students but, on many occasions, it is not contemplated.

- The importance of biographical-narrative methodology in highlighting the subjective experiences of the participants and making their voices heard.

- The sample: a diverse group of 44 students (the different types of disabilities present in the studied university were represented, and the students were from various fields of knowledge).

- The disabled student population viewed as an opportunity to improve higher education institutions.

\section{Introduction}

Diversity and inclusion in higher education (HE) can be seen as an opportunity or a problem. Authors such as Shaw (2009) argue that students can learn from each

\footnotetext{
*Corresponding author. Email: anabelm@us.es
} 
other, enriching both the classroom and the HE institution. Studies by Higbee, Siaka, and Bruch (2007) show that diversity in HE is perceived by students as enhancing the educational experience. However, for truly inclusive education to become a reality, a shared learning space and timetable are not enough; new approaches to learning and teaching (curriculum design and assessment) are also required. Reform may rouse resistance rooted in the notion that change will have a negative impact on curriculum quality, or that excellence will not be achieved. From this standpoint, diversity can be perceived as problematic. Add to this the fact that all students do not have access to the same opportunities and that some face barriers that make them question their very presence at the university. This is often the case with disabled students, as has been demonstrated internationally in the literature (Borland and James 1999; Fuller, Bradley, and Healey 2004; Holloway 2001; Hopkins 2011; Moswela and Mukhopadhyay 2011; Nielsen 2001; Prowse 2009; Riddell, Wilson, and Tinklin 2002; Ryan and Struhs 2004; Shevlin, Kenny, and McNeela 2004; Tinklin and Hall 1999, and so forth).

Much progress has been made in terms of disability policy in HE and a number of countries have passed legislation regulating the right of disabled students to participate, learn and access equal opportunities. Australia, the United Kingdom and the United States, for example, have implemented anti-discrimination laws. In Spain, provisions for disabled students are laid out in Organic Law 4/2007 for Universities, which establishes that the principles of equal opportunity and non-discrimination must be ensured and that university environments (buildings, grounds and facilities) must be accessible. At the local level, the University of Seville - host institution for the present study ${ }^{1}$ - has approved bylaws regulating academic considerations affecting the disabled student body, including the need for curricular adaptations on the part of professors and zero-cost tuition for first and subsequent enrolments (Agreement 8/CG 9-12-08, BOUS, 12 January 2009).

$\mathrm{Be}$ that as it may, HE institutions on the whole are not prepared for the inclusion of students with disabilities, as several of the aforementioned studies agree that policy is generally reactive rather than proactive, despite legislation in different countries upholding disabled student rights to a quality education (including the necessary curricular adaptations) and access to equal opportunities (Riddell, Tinklin, and Wilson 2005). Moreover, HE environments themselves may be essentially disabling, as Borland and James (1999), Reindal (1995) and Tinklin and Hall (1999) remind us. The cited studies on disability and HE have also identified significant barriers impacting the participation, progress and success of disabled students. Such barriers are essentially attitudinal and structural in nature, or involve resource availability (Moswela and Mukhopadhyay 2011). The core findings of these studies centred on curricula and course syllabi - reveal both barriers and support in the teaching and learning processes.

Likewise, work by Castellana and Sala (2006) in Spain concludes that classrooms do not have the resources needed to guarantee inclusion, and that lecturers generally do not employ effective teaching methodologies to foster full participation. As a result, disabled students do not enjoy equal opportunities with respect to their non-disabled peers. Borland and James (1999) discuss the difficulties experienced by students with disabilities on finding themselves excluded from participating in certain practical activities, or subjected to non-adapted methodologies. It has also been noted that disabled students invest a great deal of time accessing 
information that is more easily available to other students (Borland and James 1999; Tinklin and Hall 1999).

With respect to support, disabled students value the introduction of new technologies into the curricula most, as they see information technology as aiding them to make the most of their subjects (Castellana and Sala 2006; Grimaldi and Goette 1999; Pearson 2001; Pearson and Koppi 2006). Other prized factors include extra time for examinations, the use of computers, and so forth (Hall and Tinklin 1998).

Findings from previous research contribute to the thesis proposed by Ferni and Henning (2006), Oliver and Barnes (2010), Hopkins (2011), and so forth, that barriers experienced by disabled students are environmental rather than individual, as the social model of disability suggests. This model, which serves as a basis for the present research, claims that change must take place in the environment itself, as it is here that barriers to inclusion in society and education are erected. From this standpoint, reform must start with modifying teaching and learning environments with a view to make them as inclusive as possible.

Finally, studies on the idea of tailoring the curriculum for diversity conclude that changes in this direction are beneficial to all students - enhancing teaching and learning for all (Ferni and Henning 2006; Riddell, Tinklin, and Wilson 2005; Warren 2002).

\section{Research methodology}

The findings presented here fall within the larger framework of a research project funded by the Spanish Ministry of Science and Innovation entitled 'Barriers and Support that Disabled Students Identify in the University' (Dir. Dr. Anabel Moriña). Conducted by a team of University of Seville lecturers from different departments and fields of knowledge - Education Sciences, Economics, Health Sciences and Experimental Sciences - this ongoing study (2011-2013) aims, primarily, to examine barriers and support identified by disabled university students themselves as affecting access, academic performance and overall experience. Three key objectives are:

(1) To identify, describe and explain barriers and support that students with disabilities perceive as impacting access, academic performance and overall experience.

(2) To identify, describe and explain barriers and support in university classrooms affecting disabled students.

(3) To design an online faculty training guide with a view to better respond to the specific educational needs of students with disabilities.

To this end, we opted to employ biographical-narrative methodology and conduct our research in several phases. The first phase included two stages. In the first, several discussion groups were assembled (at least one group for each of the five fields of knowledge ${ }^{2}$ ) and individual oral/written interviews were set up with 44 disabled students. In the second stage, mini life-stories were completed for 16 students who participated in the first stage. These stories are thematic in nature as we have focused on a particular life period: the university experience. Three data collection instruments were used in the preparation of these stories: life lines, focused interviews and self-reports. In the second phase of research - currently underway the life-stories of eight students who participated in the second stage were taken up 
again in order to carry out what is known in biographical-narrative methodology as in-depth life-stories and polyphony of voices (Frank 2011). A wide range of data collection techniques were used, including in-depth interviews, photography, interviews with key players in the life of each student, observations, and so forth. The final phase of the study will culminate in a proposal for an online faculty training programme on the subject of response to diversity.

The present paper focuses on the second objective of our research project and on phases I and II - specifically, on barriers and support impacting the classroom environment (curricula and syllabi). The study group consisted of students with disabilities enrolled at the University of Seville during the 2009/10 academic year. At the time, there were a total of 445 students with disabilities enrolled in the University of Seville out of a total student population of $72,358(0.6 \%)$.

The sample group ranged between 19 and 59 years of age, with an average age of 30.5 years. Of these, 22 were men, and 22 were women $-25 \%$ in the first year of university, $16 \%$ in the second, $25 \%$ in the third, $14 \%$ in the fourth and $9 \%$ in the fifth. The remaining $11 \%$ were pursuing a postgraduate degree. Sixty-three per cent of the sample population had been enrolled in the university between one and five years, while the remaining $37 \%$ had been in the university for over five years. It should be noted that $14 \%$ of the sample had been in the university for 10 years or more. With respect to type of disability ${ }^{3}$ (according to the nomenclature used by the University of Seville), 38\% were students with physical disabilities, $15 \%$ had some sort of mental disability, $36 \%$ had a sensory disability and $11 \%$ had difficulties associated with ill-health (asthma, degenerative diseases, etc.).

Finally, two types of analysis were performed. For the preparation of each story, what the literature terms a narrative analysis was carried out in the manner proposed by Goodley et al. (2004). A comparative study of all data was achieved through structural analysis (Riessman 2008) using MaxQDA10 data analysis software and a system of categories and codes, as proposed by Miles and Huberman (1994).

\section{Findings. Between two shores: curricula at the service of students or vice versa?}

As discussed in the previous section, this paper only addresses findings linked to barriers and support that disabled students identified in the course syllabi for the subjects in which they were enrolled. In other words, study participants reflected on the aspects of the curriculum that contributed to - or detracted from - their inclusion in the university classroom. Occasionally, results will be examined in context as they are presented, and taken up and discussed again in the conclusions.

The analysed data are organized around four topics: general course structure (content, attendance, etc.), course methodology, tutorial action and assessment.

\section{When syllabi are endless and resources inaccessible}

Firstly, with respect to course structure, participants questioned the Bologna Process $^{4}$ and subsequent curricular changes. In all cases, the students perceived such reforms as an obstacle. One problem students expressed repeatedly is that year-long courses have been condensed into four-month courses. Students mentioned the difficulty of keeping up in the subject; condensing course content means cramming for 
midterms, tight deadlines for completing assignments and compulsory attendance in most cases - all of which increases stress levels and even leads to dropping the subject. Participants argued that they often find it impossible to attend class regularly due to hospitalization, for example, as in the case of those with health-related disabilities. Despite this reality, based on the compulsory attendance requirement found in course syllabi and the personal experiences related by the disabled students themselves, it can be concluded that essential curricular adaptations have yet to be made:

Barriers? I think the structure of the subjects, because there were subjects that were year-long and which now take four months, and well, all the syllabi that took place in a year now take four or five months, and there is no time, I have had to drop many subjects. (RSP4 $\left.{ }^{5}\right)$

In this regard, the participants agree that disability may hamper academic performance in crucial situations (such as an examination, or being unable to attend and missing content essential to success in the subject in question). To overcome this barrier, students proposed that the classes could be recorded. They explained that despite clear consensus that recording would help in cases where proper note-taking was not possible, the response from lecturers has been negative in all cases, with no collaboration whatsoever in this direction. This attitude is not new; similar testimony appears in earlier studies (Borland and James 1999; Castellana and Sala 2006; Fuller, Bradley, and Healey 2004; Tinklin and Hall 1999).

Anyway, one lecturer said recording was not an option, but maybe, if we had questions or could not go to class, we should go to a tutorial. The problem is that many people can't go to tutorials or have missed two weeks, and that can't be made up in a tutorial ... (RCS3)

When asked which resources help or hinder the learning process, participants made frequent mention of the use of slides. Students agree that, on the whole, professors do not use this resource effectively, as slides are not made available in advance. Moreover, visually impaired students consider total reliance on visual materials to be a major barrier to learning. Such findings suggest - in line with Borland and James (1999), Fuller, Bradley, and Healey 2004 and Tinklin and Hall (1999) - that certain disabilities require alternatives to visual teaching materials, and that when visual material is used students must have access to it in advance as this will facilitate learning processes:

Normally the resources they give you are ... the materials, right? Or they give you, you get lecturers who first tell you 'no, the slides are an aid I use to teach and I don't give them out' but they give you the bibliography, give you the textbook where they're based. And personally, they haven't given me anything extra. (RSP4)

Despite such objections, the use of slides for theoretical sessions is generally valued, as they are seen as making the lesson more enjoyable, to some extent. The exception is the lecturers who merely read their slides, without providing additional content or examples that could help elucidate what is being explained. 
I don't know, for example, often there is no time to cover all the material, or we spend a lot of time on things I think aren't so important ... at least now they use PowerPoint, they don't have you copying down what they say all day, but sometimes, there are many people who just read the slides, and instead of giving more information on the subject, what they do is read and that's it. (RSP6)

Another point where participants are critical is regarding access to class notes and other materials. The vast majority of students perceive this as a disability-specific barrier and criticise the lack of foresight on the part of lecturers regarding the adaptation of resources and materials enough in advance. In the case of visual impairment this can be especially problematic. Visually impaired students in Spain rely on the Organización Nacional de Ciegos Españoles, an external service that facilitates transcription of material into Braille. It is a slow process, however, and if students are not provided with material enough in advance they will not have time to get it adapted for use in class. Similar findings appeared in two studies published over a decade ago (Borland and James 1999; Tinklin and Hall 1999) - students with disabilities spend a lot of time accessing information that is more easily available to other students:

Half the time lecturers don't know what to do, at the beginning of the semester, they tell you well I don't know what materials I'm going to use. Me? Well, since I've had this disease as long as I can remember, I already know that at the beginning of the year I have to go and talk to all my professors, tell them about my disability, and let them know what help I need. So, I say to them, look, if you can you can give me the materials early, the sooner the better"'; but half the time they don't even know what materials they're going to use or anything. (RSP9)

On the other hand, participants tend to place a good deal of value on advance access to the course bibliography, completed examination papers and good quality work by peers from previous years. Such resources are perceived as empowering the student when it comes to meeting academic requirements.

One last concern has to do with what is perceived as excessive - and occasionally subpar - course content, especially in the case of new courses with academically dense syllabi. Most of the time it is impossible to cover all of the material in the time allotted and students find that the contribution of the material to learning itself is often questionable:

Many lecturers try to really condense it all and cover absolutely everything in half the time. Often they leave almost half the syllabus out because they run short on time. There have been times when that half of the syllabus is not on the exam, but other times maybe two days before the exam they tell you such-and-such a topic is in the copy-shop. 'Go study it on your own!' There wasn't enough time in class, but it's on the exam ... (RSP7)

\section{When methodology is at the service of teaching, not at the service of learning}

Regarding the methodology used in the classroom, participants primarily identified the traditional lecture where professors transmit content and provide theoretical explanations in the form of PowerPoint presentations, and where interaction with students is very limited:

Well, I think there is still a tendency to lecture at university. (RCS7) 
This reality is not alien to other Spanish universities; as Marcelo and Estebaranz (2002), Martín (2009), Pozo and Monereo (2009) and Pozo and Pérez (2009) note, lectures are the most common teaching model. If we enter a university classroom we will probably find a professor lecturing to a (more or less numerous) group of students who are taking notes - transcribing more than writing - on what the lecturer says. Indeed, most of the time learning is assessed in terms of what students are able to reiterate on a written examination. It is worth noting that, in practice, what have been termed constructivist, student-centred or learning-centred approaches to teaching are not more widespread - despite overwhelming evidence that such approaches are more effective (Bain 2004).

Although some participants speak about lectures in neutral terms, most categorically reject the approach and question its value as a learning tool. Students feel professors fall back on this methodology out of a fear that they will not have time to cover the entire syllabus; and lecturing seems to be the only option. When asked to reflect on what they learn from lectures, the students commented: '.. they explain, we study, we take the exam and ... then what? What have I really learned?'

I reject dictation, and dictators ... you can't dictate for fifty straight minutes, I mean, I thought that was a thing of the past ... but it still happens, it's still being done ... so I ... you start dictating and you keep it up for fifty minutes, or even more, and for four months straight, it's ridiculous ... that's not the spirit of the university. (RSE3)

Assignments and projects also predominate on course syllabi, along with lectures. Participants note the difficulty entailed in completing an intense workload for each subject - exacerbated by the number of different groups they are expected to participate in - and they question the extent to which this type of work helps them prepare for future careers:

Last year I had up to five subjects per semester at one point, well four were projectbased. No way, and we were all in different groups, so people say can't do it ... I can't meet you guys today because I have to work on a project with another group. It was a nightmare. (RSP4)

Despite feeling overwhelmed, however, virtually all of the students recognized that group work, as a strategy, is a support rather than a barrier to learning. Only students majoring in Technical \& Experimental Sciences such as chemistry, architecture, computer engineering, and so forth, who - due to disability - have to miss a considerable number of class hours, disagreed. In this case, the difficulties these students experienced as part of a given group underlie their perception that group work is of limited value.

In spite of such objections, the majority of students noted that in other cases although not as frequently as they would like - target skills are acquired through case studies, debates, research projects, and so forth. They consider that, in this way, theoretical content is more applicable to real life and they are more motivated to learn. These students agreed that experiences and skills acquired through such activities were very hard to learn from a book.

Another issue that study participants were asked to reflect upon is the role and use of information technology in their courses. At the University of Seville, for example, while the Blackboard virtual learning environment is available, it is significant that this resource is not perceived as being used very often; and when it is 
employed, it is usually to group materials or assign tasks. Use of other Blackboard features such as chat, email or forums was not reported. Similar findings are presented in recent work by Claiborne et al. (2010). While a high percentage of students recognized its utility, the widespread perception is that, even when the technology is available, faculty could be more enthusiastic about using it:

We have a virtual component in two courses, but we can't use it to communicate with the professor because we still have problems with the connection. They teach, they tell you to go to the platform, to visit some website, or to do whatever you have to ... and they send you assignments, the exam or whatever. But then, really, it isn't used, this dialogue doesn't exist ... (RH2)

In spite of such perceptions, students admit that they find e-learning environments to be a positive experience, as they make it possible for people who otherwise cannot attend class for various reasons to access course materials. Students do suggest, however, that more could be made of the system if more professors got involved (in this study it was hardly used in any subject) and made better use of the wide range of features that platforms like Blackboard have to offer. That said, e-learning, as a strategy, is clearly a boon for students with disabilities, as Castellana and Sala (2006), Grimaldi and Goette (1999), Pearson (2001) and Pearson and Koppi (2006) corroborate.

\section{Tutorials: quality guided learning or formality?}

Tutorials - that is, the time professors spend working with students, either in person or online - are yet another fundamental element found on HE syllabi. While tutorials should be oriented towards listening to, understanding and resolving students' doubts, in some cases this is not the reality. Study participants spoke of situations where tutorials did not meet their needs and, therefore, were deemed of little value as a learning resource.

In my case, I have benefitted little or nothing from going to tutorials (and I assure you I have attended quite a few with great interest). Some professors go no further than to comply with university regulations, they give you a tutorial schedule ... many are in a rush and tell you to study more and pay more attention in class because everything you are asking has already been explained, they tell you to take better notes, to ask a classmate for theirs ... (RCS8)

In other cases, as RSE3 indicates, students find it practically impossible to attend tutorials because they have been scheduled at the same time as other class sessions for which the course syllabus specifies compulsory attendance:

Tutorial schedules conflict with those of the classes. Ninety-five percent of the tutorials are given by lecturers at a time which conflicts with other classes. (RSE3)

It would be advisable for faculty to take such issues into account when putting together their tutorial schedules in order to avoid overlapping timetables.

That said, it is clear that not all students have had the same negative experience with tutorials; in many cases, they are perceived as being a valuable tool in the teaching-learning process: 
Tutorials, generally very good ... usually when you talk to them, well, they see our interest in learning, in knowing more, and they are always ready to help you reach that goal ... I mean, that's what every last one has shown me. (RCS5)

\section{Assessment $=$ marks $=$ examinations?}

Assessment is the last point we will touch upon in this section on findings. Our analysis takes into account measures to adapt examinations for students with disabilities, assessment strategies and tools, and examination scheduling issues.

Examination adaptation efforts were perceived by some participants as a barrier and by others as support - the latter view being more widespread. Students reported that the following adaptation strategies were employed, among others: modification of certain graphs and diagrams to make them readable by the software for visually impaired students, increasing font size of printed text, allotting extra time for taking examinations, allowing computer use as an aid to reading the examination, and so forth. Identical findings appeared in Hall and Tinklin (1998).

In other cases, adaptation efforts are not rated positively, as it is perceived that either no measures were taken or they were insufficient in terms of meeting the needs of students with disabilities. Students mention the refusal of some lecturers to change examination dates or adapt the type of examination, despite being aware of student needs and circumstances. Hopkins (2011) also finds that no adaptations were made to the examinations:

For example, I have problems writing, so I asked if maybe I could take exams orally and they said orally no, that the best they could offer me was a multiple choice test, so I say OK, multiple choice then. (RSP6)

... And another professor also told me no, more time No. (RSP2)

With respect to assessment tools, in most cases the traditional examination was the most widespread strategy. However, in a number of cases, projects or other tasks were the assessment tool of choice. Many students agree that this latter type of assessment facilitates the acquisition of skills in a progressive way; on the other hand, they complain that group work takes too much time away from self-led learning and can be a barrier to learning at their own pace. Participants also reported that despite having completed all the recommended activities, examinations were the most valued assessment tool among lecturers.

Regarding examination scheduling, all study participants agreed that, on the whole, disabled students do not dispose of enough time to prepare; examinations are all crammed into a few weeks and very little time is scheduled between them:

I think they put all the exams very close together. That is, they should leave more space between exams ... you cram six or seven exams into two weeks or so. (RS1)

Finally, we do not wish to conclude this paper without giving voice to RSE4, who may be the best spokesperson for disabled students' perceptions regarding course syllabi:

Barriers? Barrier number one is the syllabus. I have already taken twenty-seven courses ... read twenty-seven different syllabi ... no support for disabled people. (RSE4) 


\section{Conclusions}

Inclusive curricula in HE? If we are to heed the data, there are more barriers than support for inclusion. In line with Hopkins (2011), our findings suggest HE curricula have been characterized by their rigidity, not their inclusivity. If, by inclusive education, we mean the right of all students to quality learning, active participation in the learning process and a sense of belonging to their learning environment (Booth and Ainscow 1998; Moriña 2010), then we cannot honestly say that the curricula described by the participants in this study are inclusive. Students with disabilities face a unique set of barriers throughout their university experience; HE is not a level playing field and today's university makes no promises to disabled student regarding access or short/long-term success.

Indeed one of the main barriers perceived by students is post-Bologna Accord curricular restructuring, which has meant that year-long courses have been squeezed into four months, making content virtually impossible to cover on schedule. Small wonder, then, that students denounce being overtaxed with examinations and assignments each semester, and on occasion feel they have no choice but to drop out of some subjects. Coinciding with authors such as Adams and Holland (2006), our conclusion is that it would have been desirable for all students, particularly students with disabilities, to have had a voice in the design of the new curricula; unfortunately, they did not.

In addition, with the implementation of the Bologna Accord, attendance became compulsory in the majority of courses, yet University of Seville academic policy does not contemplate distance learning options for disabled students who find it impossible to attend class regularly. This is detrimental to students who are occasionally unable to attend classes due to disability-related issues (ongoing ill-health, for example) or who have been forced to drop out of certain courses because they are held in classrooms or buildings with architectural barriers that render them inaccessible. Course syllabi, therefore, should make allowances for special disabilityrelated situations (such as those referred to by the students participating in this study) with an aim to overcome these barriers.

Also worth mentioning here are barriers relating to tutorials, which - despite being designed as a venue for learning, listening and resolving students' doubts all too often overlap with class schedules or do not fulfil the purpose for which they were intended. That said, however, we must not forget that some participants consider tutorials to be a valuable part of their education.

With regard to access to lecture notes and other course materials, the vast majority of students spoke of specific disability-bound limitations. A common complaint was the lack of foresight on the part of professors when it comes to adapting course materials enough in advance. An interesting case in point is that of visually impaired students, who depend on course materials being transcribed into Braille yet who are not always able to take advantage of this resource because they do not receive material enough in advance. In this respect, early access to the course bibliography along with sample examinations and assignments from previous years is valued very positively. As these students suggest, there are issues that - in our view - are easy to remedy, which should not be left to improvisation or the goodwill of university faculty and staff. It should be assumed that students with disabilities will be present in the classroom, and faculty and staff should ensure that all necessary materials and resources are readily available for their full inclusion. This recommen- 
dation can be extrapolated to include other potential measures aimed at adapting curricula.

As far as teaching methodology is concerned, the traditional lecture is by far the most common. This approach is unpopular among students with disabilities who cite it as not motivating and failing to foster participation and interactive learning. While research shows that the traditional lecture is the most common paradigm in Spanish university classrooms (Pozo and Monereo 2009), authors such as Bain (2004) and Martín (2009) point out numerous studies that confirm the best professors adopt what has been termed a 'constructivist', 'student-centred' or 'learning-oriented' approach to teaching. For some time now we have been aware of a number of factors that contribute towards building inclusive classrooms (for example, Hopkins and Sterns 1996): strategies such as peer tutoring, project-based learning, collaborative learning, multi-level learning, and so forth, are known today to effectively meet a wide range of educational needs. We also know that international agreements exist - such as UNESCO (2009) - regarding the role of teachers as facilitators and the role of students as protagonists of the learning process. And it is precisely this approach to learning that disabled students call for: active learning/teaching methodologies, group work and opportunities for personalized learning. Hence, participants in this study admit that they prefer those subjects that invite students to become involved, to actively participate in group tasks. However, many students are concerned by what they perceive as an excessive workload in some courses and belonging to too many different groups. Such curricular barriers lead us to the conclusion that greater coordination is needed among professors teaching the same group of students, precisely to avoid this kind of overlapping. And as authors such as Riddell, Tinklin, and Wilson (2005) have noted - and the students themselves argue - improving policies affecting students with disabilities will inevitably have a positive impact on teaching/learning processes involving the entire student body.

Undoubtedly, new technologies provide learning tools that students with disabilities appreciate and stand to benefit from, as Adams and Holland (2006) point out. Disabled students report that information technology tools are not used as frequently and effectively as they could be; a concern, as they perceive them as essential to meeting their needs. In the specific case of the University of Seville, use of the Blackboard virtual learning environment should be further promoted among faculty and staff.

Finally, with respect to assessment, participants have reported a range of different experiences. In some cases, students speak very positively of dates, duration and type of examinations being modified and other adaptation measures being taken. In others, however, little or no effort to adapt assessment to the needs of disabled students is perceived. Paradoxically, although the University of Seville has had a policy regulating this type of adaptation since 2008, in practice there are times when such measures are not considered.

In conclusion, we agree with Adams and Holland (2006) in that many of the barriers described here are not unique to people with disabilities (excessive content, inappropriate methodologies, etc.). However, for disabled students these issues can be more complex, take longer to resolve and involve becoming exposed to situations of greater vulnerability. Designing and implementing truly inclusive curricula is essential to meeting the needs of students with disabilities; yet we firmly believe that this transformation in teaching practices will ultimately enhance learning for all 
students. We will never tire of insisting that diversity in university classrooms is a golden opportunity to improve HE institutions themselves; which is why we must push the envelope and seek solutions that are proactive, not reactive.

\section{Notes}

1. 'Barriers and Support that Disabled Students Identify in the University'. Project financed by the Spanish Ministry of Science and Innovation (Dir. Dr. Anabel Moriña, EDU2010 16264).

2. The five fields of knowledge at the University of Seville are: Health Sciences; Experimental Sciences; Social Sciences (Law \& Education); Engineering \& Technology; and Humanities.

3. In contrast to other Spanish and international universities, University of Seville policy does not define specific learning challenges such as dyslexia as 'disability'.

4. The Bologna Process refers to reform undertaken by European universities leading to the creation of the European Higher Education Area. Main objectives include: adopting a common, easily understandable, comparable degree system designed to promote panEuropean employability and make the European HE system more competitive internationally; establishing a common credit system - the European Credit Transfer System in order to facilitate student mobility among European institutions of HE and lifelong learning; encouraging cooperation among European Member States aimed at developing comparable, high-quality criteria and methodologies.

5. To safeguard the confidentiality of participants in this study, the following abbreviations are used to identify them: $\mathrm{RSC}=$ Health Sciences; RSE $=$ Social Sciences (Law); $\mathrm{RSP}=$ Social Sciences (Education); RTE $=$ Engineering, Technology \& Experimental Sciences; $\mathrm{RH}=$ Humanities.

\section{References}

Adams, M., and S. Holland. 2006. "Improving Access to Higher Education for Disabled People." In Towards Inclusive Learning in Higher Education, edited by M. Adams and S. Brown, 10-22. London: Routledge.

Bain, K. 2004. What the Best College Teachers Do. Cambridge MA: Harvard University Press.

Booth, T., and M. Ainscow. 1998. From Them to Us. London: Routledge.

Borland, J., and S. James. 1999. "The Learning Experience of Students with Disabilities in Higher Education. A Case Study of a UK University." Disability \& Society 14 (1): 85-101.

Castellana, M., and I. Sala. 2006. Estudiantes Con Discapacidad en la Universidad. Barcelona: Edición Producida y Coordinada por la Fundació Blanquerna Assistencial i de Serveis.

Claiborne, L., S. Cornforth, A. Gibson, and A. Smith. 2010. "Supporting Students with Impairments in Higher Education: Social Inclusion or Cold Comfort?" International Journal of Inclusive Education 15 (5): 513-527.

Ferni, T., and M. Henning. 2006. "From a Disabling World to a New Vision." In Towards Inclusive Learning in Higher Education, edited by M. Adams and S. Brown, 23-31. London: Routledge.

Frank, A. W. 2011. "Practicing Dialogical Narrative Analysis." In Varieties of Narrative Analysis, edited by J. A. Holstein and J. F. Gubrium, 33-52. Los Angeles: Sage Publications.

Fuller, M., A. Bradley, and M. Healey. 2004. "Incorporating Disabled Students within an Inclusive Higher Education Environment." Disability \& Society 19 (5): 455-468.

Goodley, D., R. Lawthom, P. Clough, and M. Moore. 2004. Researching Life Stories. London: Routledge.

Grimaldi, C., and T. Goette. 1999. "The Internet and the Independence of Individuals with Disabilities." Internet Research 9 (4): 272-280.

Hall, J., and T. Tinklin. 1998. The Experiences of Disabled Students in Higher Education. Glasgow: The Scottish Council for Research in Education. 
Higbee, J. L., K. Siaka, and A. L. Bruch. 2007. "Student Perceptions of their Multicultural Learning Environment: a Closer Look." In Diversity and the Postsecondary Experience, edited by J. L. Higbee, D. B. Lundell, and I. M. Duranczyk, 3-24. Minnesota: Centre for Research on Developmental Education and Urban Literacy.

Holloway, S. 2001. "The Experience of Higher Education from the Perspective of Disabled Students." Disability \& Society 16 (4): 597-615.

Hopkins, L. 2011. "The Path of Least Resistance: A Voice-Relational Analysis of Disabled Students' Experiences of Discrimination in English Universities." International Journal of Inclusive Education 15 (7): 711-727.

Hopkins, D., and D. Sterns. 1996. "Quality Teachers, Quality Schools: International Perspectives and Policy Implications." Teaching and Teacher Education 12 (5): 501-517.

Marcelo, C., and A. Estebaranz. 2002. "Marco General de Investigación Sobre la Enseñanza en la Universidad." In Enseñanza y Aprendizaje en la Educación Superior, coord. C. Mayor, October 7-26, Barcelona.

Martín, E. 2006. "Profesorado Competente Para Formar Alumnado Competente: El Reto Del Cambio Docente." In Psicología del Aprendizaje Universitario: La Formación En Competencias, edited by J. I. Pozo and M. P. Pérez, 199-215. Madrid: Morata.

Miles, M. B., and A. M. Huberman. 1994. Qualitative Data Analysis. Los Angeles: Sage Publications.

Moriña, A. 2010. "School Memories by Young People With Disbilities: An Analysis of Barriers and Aids to Inclusion." Disability \& Society 25 (2): 163-175.

Moswela, E., and S. Mukhopadhyay. 2011. "Asking for too much? The Voices of Students with Disabilities in Botswana." Disability \& Society 26 (3): 307-319.

Nielsen, J. A. 2001. "Successful University Students with Learning Disabilities." Journal of College Student Psychotherapy 15 (4): 37-48.

Oliver, M., and C. Barnes. 2010. "Disability Studies, Disabled People and the Struggle for Inclusion." British Journal of Sociology of Education 31 (5): 547-560.

Pearson, E. J. (2001) "Strategies for Developing Inclusive Online Courses." Paper presented at WebCT Asia-Pacific Conference, Adelaide, Australia, April 10.

Pearson, E., and T. Koppi. 2006. "Supporting Staff in Developing Inclusive Online Learning." In Towards Inclusive Learning in Higher Education, edited by M. Adams and S. Brown, 56-66. London: Routledge.

Pozo, J. I., and C. Monereo. 2006. "Introducción: La Nueva Cultura Del Aprendizaje Universitario O Por Qué Cambian Nuestras Formas de Enseñar y Aprender." In Psicología del Aprendizaje Universitario: La Formación en Competencias, edited by J. I. Pozo and M. P. Monereo, 9-28. Madrid: Morata.

Pozo, J. I., and M. P. Pérez. 2006. "Aprender Para Comprender y Resolver Problemas." In Psicología del Aprendizaje Universitario: La Formación en Competencias, edited by J. I. Pozo and M. P. Monereo, 31-53. Madrid: Morata.

Prowse, S. 2009. "Institutional Construction of Disabled Students." Journal of Higher Education Policy and Management 31 (1): 89-96.

Reindal, S. M. 1995. "Some Problems Encountered by Disabled Students at the University of Oslo - Whose Responsibility?" The European Journal of Special Needs 10 (3): $227-241$.

Riddell, S., T. Tinklin, and A. Wilson. 2005. Disabled Students in Higher Education. London: Routledge.

Riddell, S., A. Wilson, and T. Tinklin. 2002. "Disability and the Wider Access Agenda: Supporting Disabled Students in Different Institutional Contexts." Widening Participation and Lifelong Learning 4: 12-26.

Riessman, C. K. 2008. Narrative Methods for the Human Sciences. Los Angeles: Sage Publications.

Ryan, J., and J. Struhs. 2004. "University Education for All? Barriers to Full Inclusion of Students with Disabilities in Australian Universities." International Journal of Inclusive Education 8 (1): 73-90.

Shaw, J. 2009. "The Diversity Paradox: Does Student Diversity Enhance or Challenge Excellence?" Journal of Further and Higher Education 33 (4): 321-331.

Shevlin, M., M. Kenny, and E. Mcneela. 2004. "Participation in Higher Education for Students with Disabilities: An Irish Perspective.” Disability \& Society 19 (1): 15-30. 
Tinklin, T., and J. Hall. 1999. "Getting Round Obstacles: Disabled Students' Experiences in Higher Education in Scotland." Studies in Higher Education 24: 183-194.

UNESCO. 2009. Second Collection of Good Practices. Education for Sustainable Development. Paris: UNESCO.

Warren, D. 2002. "Curriculum Design in a Context of Widening Participation in Higher Education." Arts and Humanities in Higher Education 1 (1): 85-99. 